\title{
Peningkatan Kadar Zn Beras Pecah-Kulit pada Sistem Penggenangan Berselang Melalui Aplikasi Pupuk Kandang Diperkaya Zn Heptahidrat
}

\section{(Improvement of Zn Level of Brown Rice On Intermittent Flooding Fertilized through Application of Zn Heptahydrate-Enriched Cow Manure)}

\author{
Salawati ${ }^{*}$, Sjarifuddin Ende ${ }^{1}$, Mohammad Basir $^{2}$, Indrianto Kadekoh ${ }^{2}$, Abdul Rahim Thaha ${ }^{2}$
}

(Diterima Januari 2021/Disetujui September 2021)

\begin{abstract}
ABSTRAK
Kadar $\mathrm{Zn}$ dalam beras penting untuk menjaga kesehatan konsumen. Defisiensi $\mathrm{Zn}$ dalam tanaman dapat berakibat turunnya kadar $\mathrm{Zn}$ dalam bulir serta kemampuan tanaman tersebut mengekpresikan potensi genetiknya. Penelitian ini bertujuan mengevaluasi penggunaan pupuk kandang sapi yang diperkaya $\mathrm{Zn}$-heptahidrat pada peningkatan kadar $\mathrm{Zn}$ beras pecah-kulit. Percobaan disusun dalam rancangan acak kelompok faktor tunggal dengan tujuh taraf perlakuan dosis pupuk kandang, yaitu $0 ; 2,5 ; 5 ; 7,5 ; 10 ; 12,5 ; 15$ ton ha-1, dengan 3 ulangan. Jarak tanam adalah 30 $\mathrm{cm} \times 30 \mathrm{~cm}$ dengan ukuran petak $3 \mathrm{~m} \times 4 \mathrm{~m}$. Parameter yang diamati antara lain pertumbuhan tanaman, bobot 1.000 butir gabah, persentase gabah hampa, produksi, kadar $\mathrm{Zn}$, dan protein beras pecah-kulit. Data yang terkumpul dianalisis menggunakan sidik ragam dengan selang kepercayaan $5 \%$, dan dilanjutkan dengan uji Duncan $5 \%$. Hasil penelitian menunjukkan bahwa aplikasi pupuk kandang sapi dosis 12,5 ton ha-1 yang dikayakan $\mathrm{Zn}$-heptahidrat $5 \mathrm{~kg}^{-1}$ ha $^{-1}$ dapat meningkatkan jumlah anakan produktif $(35,20$ anakan), bobot 1.000 butir $(28,02 \mathrm{~g})$, produksi $(8,48$ ton ha-1), kadar Zn (37 ppm), dan protein beras pecah-kulit $(8,69 \%)$, serta menekan gabah hampa $(5,99 \%)$ varietas Mekongga budi daya padi sawah pola penggenangan berselang.
\end{abstract}

Kata kunci: beras pecah-kulit, pupuk kandang sapi, sistem pengairan, Zn heptahidrat

\section{ABSTRACT}

$\mathrm{Zn}$ levels in rice are essential for maintaining consumer health. However, $\mathrm{Zn}$ deficient plants can reduce levels of $\mathrm{Zn}$ in grains and the ability of plants to express their genetic potentials. This study examines the use of cow manure enriched with $\mathrm{Zn}$ heptahydrate on increasing $\mathrm{Zn}$ levels of broken skin rice. The experiment was arranged in a randomized single factor group design with seven levels of manure dose treatment, namely: $0 ; 2.5 ; 5,7.5,10,12.5,15$ tons ha $^{-1}$, with 3 replications. Spacing was $30 \mathrm{~cm}$ x $30 \mathrm{~cm}$ with a size of $3 \mathrm{~m} \times 4 \mathrm{~m}$. The parameters observed were plant growth, the weight of 1,000-grain, percentage of empty grain, production, $\mathrm{Zn}$ and protein contents of the brown rice. The collected data were analyzed using analysis of variance with a confidence interval of $5 \%$, followed by the Duncan test of $5 \%$. The results showed that the application of cow manure with a dose of 10 tons ha-1 enriched by 5 $\mathrm{kg} \mathrm{ha}^{-1} \mathrm{Zn}$ heptahydrate could increase the number of productive tillers, weight of 1,000-grains, production, $\mathrm{Zn}$ and protein contents of the brown rice as well as suppress the grainy rice grain of Mekongga variety of lowland rice on the intermittent flooding.

Keywords: brownrice, cow manure, irrigation system, Zn heptahydrate

\section{PENDAHULUAN}

Fungsi utama tanah sawah bagi pertanian adalah sebagai tempat tumbuh tanaman padi; kemampuannya akan optimum jika didukung oleh kondisi fisik, kimia, dan biologi tanah yang sesuai. Tindakan pemupukan yang dipraktikkan selama ini bertujuan meningkatkan produksi. Pupuk yang dominan digunakan sebatas pupuk makro, yaitu N, P, dan K, dalam

1 Jurusan Petanian, Sekolah Tinggi Pertanian Mujahidin Tolitoli, JI. Dr. Sam Ratulangi No. 51, Tuweley, Tolotoli, Sulawesi Tengah, 94515

2 Jurusan Agroteknologi, Fakultas Pertanian, Universitas Tadulako, Jl. Ir. Soekarno Hatta Km. 9, Palu, Sulawesi Tengah, 94148

* Penulis Korespondensi:

Email: wati.lasandrang@gmail.com dosis yang tinggi dengan jangka waktu yang lama, yang menyebabkan ketidakseimbangan antara hara makro dan mikro (Purnomo et al. 2011; Solomon et al. 2014; Supadma et al. 2013; Yulnafatmawita et al. 2014; Ardianti \& Sudiarso 2019; Saputra \& Mulyawan 2021). Terganggunya keseimbangan hara berdampak pada hasil dan kualitas padi sawah.

Ukuran kualitas beras selama ini mengacu pada standar fisik seperti beras pecah, panjang bulir, diameter, keterawangan, dan derajat sosoh (Indrasari et al. 2007; Wibisono \& Mujiyono 2018; Arsyad \& Saud 2020). Sementara terkait dengan kandungan protein dan kadar $\mathrm{Zn}$ dalam beras belum banyak diungkap. Devar et al. (2011) menyatakan bahwa beras menyediakan $21 \%$ energi dan $15 \%$ kebutuhan protein populasi manusia secara global dan juga dapat menyediakan nutrisi mineral seperti $\mathrm{Zn}$. Kandungan $\mathrm{Zn}$ 
pada beras pecah-kulit rata-rata 15-22 ppm (Indrasari 2006) atau termasuk kategori rendah. Sementara $90 \%$ masyarakat Indonesia menempatkan beras sebagai makanan pokoknya, konsumsi beras berkadar $\mathrm{Zn}$ rendah dapat mengakibatkan defisiensi nutrisi $\mathrm{Zn}$ (Ratmini 2014; Rengel 2015; Welch\& Graham 2004), yang dapat memicu penyakit kanker (Prasad 2014), khususnya bagi masyarakat berpenghasilan rendah.

Penyebab rendahnya kadar $\mathrm{Zn}$ pada beras antara lain karena sistem budi daya padi yang diterapkan (Yullianida et al. 2014; Alloway 2008), status kadar Zn tanah rendah dan sangat rendah (Hamam et al. 2017; Supadma et al. 2013). Hal tersebut terjadi karena orientasi petani lebih ditujukan pada peningkatan kuantitas (produksi). Alternatif untuk mengatasi permasalahan tersebut ialah melalui inovasi teknologi budi daya antara lain penggunaan pupuk organik yang diperkaya $\mathrm{Zn}$, yang berperan penting dalam menciptakan kesuburan tanah secara fisik, kimia, dan biologi tanah, sumber nutrisi dan energi bagi biota tanah serta sebagai sumber hara (Esmaeilzadeh \& Ahangar 2014; Zahrah 2011).

Tanah sawah sangat berisiko kekurangan $\mathrm{Zn}$. Pada tanah tergenang, kadar $\mathrm{Zn}$ akan menurun. Penggenangan meningkatkan $\mathrm{pH}$ tanah yang menyebabkan pembentukan $\mathrm{Zn}$ sulfat dan peningkatan kadar ion besi(II) dan mangan(II). Aktivitas ion-ion tersebut sangat memengaruhi penyerapan $\mathrm{Zn}$ oleh akar (Alloway 2008). Penggunaan bahan organik dapat meningkatkan aktivitas mikroorganisme yang dapat membantu meningkatkan ketersediaan unsur hara mikro termasuk Zn (Mishra 2014; Salawati et al. 2018; Sillanpaa1982), tetapi tidak cukup. Tambahan $\mathrm{Zn}$ pada pupuk diperlukan untuk meningkatkan kadar Zn pada tanah sawah. Beberapa hasil penelitian menunjukkan bahwa aplikasi pupuk organik dan pupuk $\mathrm{Zn}$ dapat meningkatkan kadar Zn pada bulir padi. Aplikasi pupuk kandang sapi 15 ton ha-1 dapat meningkatkan kadar $\mathrm{Zn}$ pada bulir padi, (Solomon et al. 2014), penggunaan pupuk Zn (Tabassum et al. 2014), penggunaan biochar yang dikayakan $\mathrm{Zn}$ heptahidrat $10 \mathrm{~kg} \mathrm{ha}^{-1}$ dapat meningkatkan serapan hara Zn (Salawati et al. 2018). Akan tetapi, pengaruh pupuk kandang yang diperkaya dengan pupuk Zn pada pola penggenangan berselang pada produksi dan kualitas padi/beras belum banyak dikaji. Penelitian ini bertujuan mengevaluasi peran pupuk kandang sapi yang diperkaya $\mathrm{Zn}$ pada sistem pengairan berselang dan pengaruhnya pada peningkatan kadar Zn beras pecah-kulit.

\section{METODE PENELITIAN}

Penelitian ini dilaksanakan di kebun percobaan (KP) Balai Pengkajian Teknologi Pertanian Sulawesi Tengah Sidondo Kabupaten Sigi Biromaru, Provinsi Sulawesi Tengah, mulai bulan Februari sampai Juni 2017.

Rancangan lapangan yang digunakan adalah rancangan acak kelompok (RAK) 7 taraf perlakuan dengan 3 ulangan, masing-masing petak berukuran 3 $\mathrm{m} \times 4 \mathrm{~m}$. Jarak antar-ulangan $0,75 \mathrm{~m}$ dan antar-petak $0,5 \mathrm{~m}$. Untuk menghindari percampuran air masuk dan yang dilepas pada petak percobaan dibuatkan kanalkanal air. Perlakuan percobaan dosis $0 ; 2,5 ; 5 ; 7,5 ; 10$; 12,5; dan 15 ton ha $^{-1}$ yang disimbolkan P0 s.d. P6 dan setara dengan $0 \mathrm{~kg} \mathrm{s.d.} 18 \mathrm{~kg}_{\text {petak }}{ }^{-1}$ yang dikayakan pupuk $\mathrm{Zn}$ heptahidrat $5 \mathrm{~kg}$ ha $^{-1}\left(6 \mathrm{~g}_{\text {petak }}{ }^{-1}\right)$, serta pembenah tanah berupa biochar sekam padi 2 ton ha$1\left(2,4 \mathrm{~kg} \mathrm{petak}^{-1}\right)$.

Lahan diolah menggunakan traktor, kemudian dibiarkan tergenang untuk mematikan gulma dan residu pestisida pada tanah selama 14 hari, selanjutnya digaru dan dibuat petak percobaan sesuai dengan desain. Setiap petak diberi biochar (2 ton ha-1 atau 2,4 $\mathrm{kg}$ petak $^{-1}$ ) dengan takaran yang sama dan pupuk kandang sapi sesuai dengan perlakuan. Tanah kemudian digenangi sampai kondisi tanahnya macak selama 1 pekan sebelum tanam.

Benih bernas dipilih dengan cara merendamnya dalam larutan air garam (125 g garam dalam 1 liter air). Benih yang digunakan adalah benih yang tenggelam, lalu benih dicuci dengan air hingga bersih dari larutan garam, direndam selama 24 jam, lalu diinkubasi selama 24 jam. Benih disemaikan di kotak persemaian berukuran $50 \mathrm{~cm} \times 20 \mathrm{~cm} \times 5 \mathrm{~cm}$ yang telah diisi tanah bercampur pupuk kandang sapi dan biochar sekam padi dengan nisbah 1:1:1, tinggi tanah persemaian 5 $\mathrm{cm}$. Benih ditabur kemudian ditutup tanah tipis, ditempatkan di tempat yang terlindung dari sinar matahari langsung.

Setelah berumur 12 HSS (Krishna 2006) jarak tanam 30 x 30 cm (Ceesay 2004; Krishna 2006) benih ditanam, 1 bibit per lubang, ditanam dangkal sedalam $2 \mathrm{~cm}$ dengan bentuk perakaran horizontal (bentuk L), pada tempat yang telah ditentukan dengan menggunakan caplak. Setelah itu, petak percobaan digenangi air setinggi $1 \mathrm{~cm}$ sampai umur $5 \mathrm{HST}$, kemudian tinggi genangan dinaikkan $2 \mathrm{~cm}$ sampai masa pengeringan. Petakan dikeringkan sebanyak 5 kali, yaitu pada saat tanaman berumur 11-15, 26-30, 41-45, 56-60, dan 96 HST sampai panen, mengacu pada metode Purba (2011). Air dialirkan ke dalam petakan melalui kanal di samping petakan.

Pemeliharaan meliputi pemupukan urea $100 \mathrm{~kg}$ ha $^{-1}$ yang diaplikasikan dua kali; aplikasi pertama sehari sebelum tanam dosis $50 \mathrm{~kg} \mathrm{ha}^{-1}$ dan yang kedua pada umur $35 \mathrm{HST}$ sebanyak $50 \mathrm{~kg} / \mathrm{ha}$. Pupuk SP-36, $\mathrm{KCl}, \mathrm{ZnSO}_{4} 7 \mathrm{H}_{2} \mathrm{O}$ dengan dosis masing-masing (50:50:5) kg ha-1 juga diaplikan sehari sebelum tanam. Penyiangan gulma, pengendalian hama dan penyakit diterapkan bergantung pada kondisi serangan.

Hasil dipanen dengan menyabit rumpun contoh sewaktu tanaman berumur 108 hari setelah semai. Saat itu padi telah menguning lebih dari $90 \%$ pada satu rumpun dan daun bendera mulai mengering.

Variabel respons yang diamati pada percobaan ini adalah tinggi tanaman, yang diukur dari permukaan tanah sampai ujung daun yang terpanjang. Jumlah anakan-terbentuk dihitung dengan cara menghitung 
semua anakan yang terbentuk. Data diambil saat tanaman berumur 15, 30, 45, dan $60 \mathrm{HST}$; jumlah anakan produktif, dihitung dengan cara menghitung semua anakan yang produktif (menghasilkan bulir padi) saat menjelang panen. Persentase gabah hampa dihitung dengan cara mengambil $20 \%$ malai pada setiap sampel gabah bernas dan gabah hampa. Bobot 1.000-butir gabah bernas ditimbang dari sampel yang diambil secara acak dan telah ditimbang bobot keringnya. Produksi ton ha ${ }^{-1}$ gabah kering giling dihitung dengan menimbang hasil ubinan kering panen dengan standar kadar air 14\%. Kandungan Zn bulir padi dianalisis menggunakan instrumen spektroskopi serapan atom pada contoh kering $105^{\circ}$ menggunakan $\mathrm{HNO}_{3}$. Kandungan protein bulir padi, dianalisis dengan metode Kejhdal:

Kadar air 14\% ditentukan dengan cara

Produksi

$$
=\frac{100-\text { kadar air panen }}{100-14} \times \text { produksi ubinan }
$$

$$
=\frac{\text { luas }(\text { ha })}{\text { luas petak ubinan }} \times \text { produksi ubinan kadar air } 14 \%
$$

Kandungan protein

$$
=\frac{\mathrm{mL} \mathrm{HCl}(\mathrm{c}-\mathrm{b}) \times \mathrm{N} \times \text { faktor pengenceran } \times 14 \times 5,95}{\text { bobot contoh }} \times 100 \%
$$

Keterangan:

$\mathrm{c}=$ contoh; $\mathrm{b}=$ blanko; $\mathrm{N}=$ normalitas $\mathrm{HCl}$ (Sudarmaji et al. 1984).

\section{HASIL DAN PEMBAHASAN}

Hasil analisis tanah awal menunjukkan bahwa kadar Zn dalam tanah rendah (18,22 ppm) (Alloway 2008; Mousavi 2011). Idealnya kadar Zn dalam tanah adalah 50 ppm (Alloway 2008), serta ketersediaannya sangat tergantung pada mineral, endapan per lokasi, difusi, unsur bersifat antagonis ( $\mathrm{P}, \mathrm{Fe}, \mathrm{Mn}, \mathrm{Ca})$, keberadaan gulma, mikrob, serta kadar bahan organik tanah yang saling berhubungan satu sama lain. Tekstur tanah lempung berpasir, kadar hara (Tabel 1).

\section{Tinggi Tanaman}

Hasil percobaan menunjukkan bahwa perlakuan pupuk kandang sapi 15 ton ha- ${ }^{-1}$ dapat meningkatkan pertambahan tinggi tanaman padi bila dibandingkan dengan kontrol, walaupun secara statistik tidak berbeda nyata (Gambar 1). Tinggi tanaman sangat dipengaruhi oleh faktor genetik varietas padi (Kaihatu \& Pasireron, 2011), akan tetapi tinggi tanaman lebih banyak dipengaruhi oleh faktor lingkungan (Gardner 1991; Jalali-moridani \& Amiri 2014)

\section{Jumlah Anakan}

Perlakuan yang dicobakan secara statistik tidak memengaruhi tanaman umur muda. Hubungan antara dosis perlakuan dan umur tanaman sangat kuat; perlakuan dosis 2,5 ton ha-1 berpengaruh nyata saat tanaman berumur 30 dan 45 HST, sedangkan dosis 5 ton ha $^{-1}$ pada umur $60 \mathrm{HST}$. Hal ini diduga karena semakin dewasa tanaman, semakin tinggi kebutuhan

\begin{tabular}{|c|c|c|c|}
\hline No & Parameter & Nilai & Satuan \\
\hline 1 & $\mathrm{pH} \mathrm{H}_{2} \mathrm{O}(1: 25)$ & 7,70 & - \\
\hline 2 & C-Organik & 1.09 & $\%$ \\
\hline 3 & N-Total & 0,10 & $\%$ \\
\hline 4 & $\mathrm{P}_{2} \mathrm{O}_{5}$ (Olsen) & 12,61 & ppm \\
\hline 5 & $\mathrm{~K}_{2} \mathrm{O}(\mathrm{HCl} 25 \%)$ & 35,48 & $\mathrm{mg} 100 \mathrm{~g}^{-1}$ \\
\hline 6 & Kalsium (Ca) & 9,13 & $\mathrm{cmol}(+) \mathrm{kg}^{-1}$ \\
\hline 7 & Kalium $(\mathrm{K})^{\prime}$ & 0,43 & $\operatorname{cmol}(+) \mathrm{kg}^{-1}$ \\
\hline 8 & Natrium $(\mathrm{Na})$ & 0,51 & $\mathrm{cmol}(+) \mathrm{kg}^{-1}$ \\
\hline 9 & $\mathrm{Cu}$ Total (Ekstrak $\mathrm{HNO}_{3}$ dan $\mathrm{HClO}_{4}$ ) & 2,02 & ppm \\
\hline 10 & Mn Total (Ekstrak $\mathrm{HNO}_{3}$ dan $\left.\mathrm{HClO}_{4}\right)$ & 17,84 & ppm \\
\hline 11 & Zn Total (Ekstrak $\mathrm{HNO}_{3}$ dan $\left.\mathrm{HClO}_{4}\right)$ & 18,22 & ppm \\
\hline 12 & Fe Total (Ekstrak $\mathrm{HNO}_{3}$ dan $\left.\mathrm{HClO}_{4}\right)$ & 53,90 & ppm \\
\hline
\end{tabular}
akan hara; selain itu tambahan biochar ( 2 ton ha-1)

Tabel 1 Kandungan unsur hara dalam tanah sebelum penelitian

Sumber: Data primer hasil analisis Lab tanah Universitas Tadulako Palu

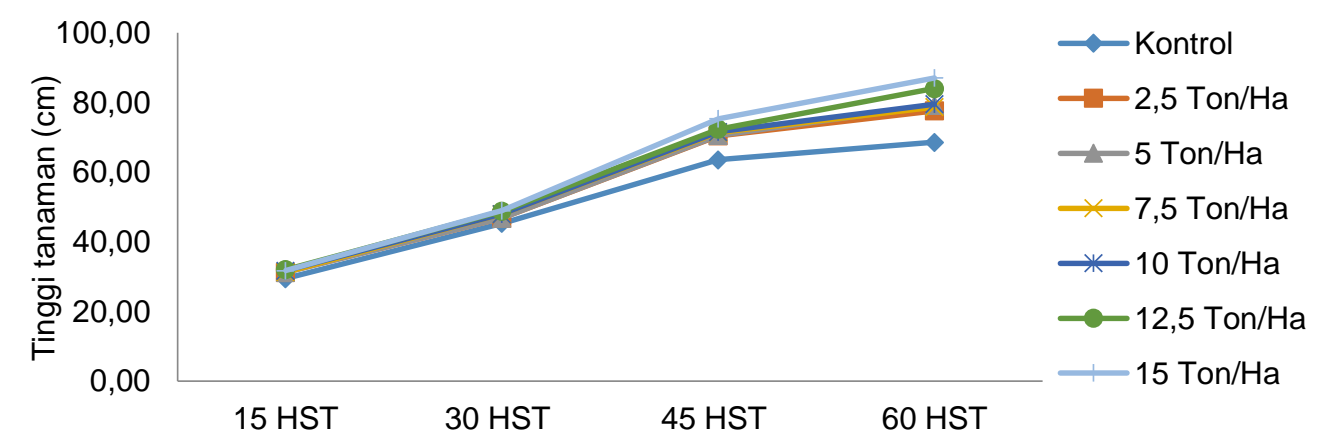

Gambar 1 Tinggi tanaman padi varietas Mekongga yang diberi pupuk kandang sapi diperkaya $\mathrm{Zn}$ pada berbagai umur pengamatan 
sebagai pembenah tanah dapat meningkatkan peran dan fungsi pupuk kandang.

Selain peran biochar, pupuk Zn, dan pupuk kandang sapi, sistem olah tanam juga memberi pengaruh. Sistem penggenangan berselang (5 hari kering dan 10 hari basah) meningkatkan jumlah anakan. Tanaman padi membutuhkan energi untuk pembentukan dan aktivitas aerenkima dalam kondisi tergenang sehingga tanaman padi kekurangan energi dalam membentuk anakan. Dalam kondisi tidak tergenang sistem perakaran dapat berkembang maksimum. Pada kondisi tersebut tanah mampu menyediakan oksigen dalam jumlah yang cukup untuk melakukan respirasi dan membentuk anakan. Jumlah anakan dalam penelitian ini rata-rata 30,49, melampau jumlah anakan tanaman padi dalam sistematika tanaman padi varietas Mekongga, yaitu rata-rata 13-16 batang per rumpun. Menurut Mahmud et al. (2011) jumlah anakan padi varietas ini pada umur 43 hari mencapai 16,7-18,7 anakan. Anakan terbentuk lebih banyak bila tanaman mendapat sinar matahari, udara, dan hara (Wangiyana et al. 2009). Penelitian ini tidak sejalan dengan Rozen et al. (2017) yang melaporkan bahwa penggunaan pupuk mikro Mn dan Zn 9 kg ha-1 dan pupuk organik pada budi daya SRI tidak memberikan pengaruh berbeda.

\section{Persentasi Gabah Hampa}

Persentase gabah hampa menurun seiring dengan bertambahnya dosis pupuk kandang sapi (Tabel 2). Hal ini dimungkinkan karena pupuk kandang sapi dapat melepas nutrisi yang dibutuhkan tanaman selama proses pertumbuhannya, biochar menahan proses pelepasan unsur hara yang berasal dari pupuk kandang sapi, $\mathrm{Zn}$ yang berperan dalam metabolisme tanaman secara sinergi mendukung pertumbuhan sehingga malai hampa menjadi berkurang. Temuan ini mendukung Solomon et al. (2014), yang menyatakan bahwa malai hampa berkurang seiring dengan meningkatnya dosis pupuk kandang sapi. Persentase malai hampa meningkat berkaitan dengan besaran hasil asimilasi yang ditranslokasikan ke organ produksi seperti malai dan kompetisi di antara jumlah anakan yang terbentuk sehingga tidak semua anakan yang terbentuk menghasilkan malai yang berisi (Rehman et al. 2012). Pada setiap tahap pertumbuhan tanaman padi, hal ini sejalan dengan Boonchuay et al. (2013) yang menyatakan bahwa aplikasi Zn ke dalam tanah mampu mencukupi kebutuhan $\mathrm{Zn}$ pada setiap pertumbuhan tanaman, sehingga memengaruhi pengurangan persentase gabah hampa. Lebih lanjut Azalika et al. (2018) melaporkan bahwa penggunaan pupuk kandang sapi 20 ton ha ${ }^{-1}$ memberikan persentase bulir bernas $97,26 \%$ bila dibandingkan dengan yang tanpa aplikasi pupuk kandang. Sementara itu aplikasi pupuk kandang sapi yang diperkaya $\mathrm{Zn}$ pada penelitian ini dapat menekan gabah hampa hingga $96,5 \%$.

\section{Bobot 1.000-Butir}

Pemberian pupuk kandang sapi yang diperkaya $\mathrm{Zn}$ memengaruhi peningkatan bobot 1.000-butir gabah. Bobot gabah sangat dipengaruhi oleh biomassa yang terkandung dalam gabah; gabah yang semakin berat menandakan biomassa yang terkandung semakin banyak. Hal ini disebabkan terjaminnya fungsi fisiologis tanaman dan ketersediaan hara. Peningkatan bobot kering 1.000 butir gabah dipengaruhi oleh kemampuan tanaman dalam menghasilkan asimilat yang disimpan dalam organ produksi, yang berhubungan erat dengan ketersediaan kadar bahan organik (pupuk kandang sapi) yang mendukung kemampuan tanah dalam memasok hara (Janušauskaitè et al. 2013). Selanjutnya Wahyudi (2009) menyatakan bahwa bahan organik merupakan sumber unsur hara $\mathrm{N}, \mathrm{P}$, dan $\mathrm{S}$ bagi tanaman, dengan demikian meningkatnya bahan organik berarti akan meningkatkan ketersediaan unsur -unsur tesebut bagi tanaman, dan selanjutnya meningkatkan bobot kering tanaman termasuk bobot bulir.

Pupuk kandang sapi yang diaplikasikan sebagai sumber bahan organik berperan memperbaiki kemampuan menahan air, menyediakan hara makro dan mikro bagi tanaman, memperbaiki struktur tanah, dan menetralkan pH tanah (Tekwa et al. 2010). Hal ini karena pupuk kandang sapi yang bersifat alifatik dan biochar bersifat aromatik berpori yang mampu menyerap dan menyimpan air meskipun pada saat pengeringan lahan, sehingga mampu mempertahankan kelembapan yang optimum bagi perkembangan akar tanaman dan menjaga ketersediaan hara dari berbagai proses kehilangan. Hasil pengamatan ini sejalan dengan pernyataan Siregar et al. (2013) bahwa aplikasi pupuk organik mampu meningkatkan bobot

Tabel 2 Persentase gabah hampa, bobot 1.000-butir, kadar protein dan Zn beras pecah-kulit, dan produksi padi yang diberi pupuk kandang sapi diperkaya Zn pada sistem budi daya pola SRI

\begin{tabular}{lccccc}
\hline $\begin{array}{c}\text { Perlakuan dosis pupuk } \\
\text { kandang sapi ton ha }{ }^{-1}\end{array}$ & $\begin{array}{c}\text { Persentase } \\
\text { gabah hampa }\end{array}$ & $\begin{array}{c}\text { Bobot 1.000- } \\
\text { butir }\end{array}$ & $\begin{array}{c}\text { Kadar protein beras } \\
\text { pecah-kulit (\%) }\end{array}$ & $\begin{array}{c}\text { Kadar Zn beras } \\
\text { pecah-kulit (ppm) }\end{array}$ & $\begin{array}{c}\text { Produksi } \\
\text { (ton ha-1) }\end{array}$ \\
\hline Kontrol & $11,77 \mathrm{a}$ & $25,49 \mathrm{a}$ & $6,41 \mathrm{a}$ & $21,00 \mathrm{a}$ & $6,01 \mathrm{a}$ \\
2,5 & $9,26 \mathrm{bc}$ & $27,14 \mathrm{bc}$ & $7,63 \mathrm{bc}$ & $32,00 \mathrm{c}$ & $7,18 \mathrm{~b}$ \\
5 & $9,10 \mathrm{c}$ & $27,19 \mathrm{bc}$ & $7,81 \mathrm{bc}$ & $29,33 \mathrm{bc}$ & $7,56 \mathrm{~b}$ \\
7,5 & $9,10 \mathrm{c}$ & $27,64 \mathrm{c}$ & $7,82 \mathrm{bc}$ & $31,67 \mathrm{bc}$ & $7,66 \mathrm{c}$ \\
10 & $6,69 \mathrm{ed}$ & $27,54 \mathrm{c}$ & $8,69 \mathrm{c}$ & $33,00 \mathrm{~d}$ & $8,48 \mathrm{c}$ \\
12,5 & $5,99 \mathrm{e}$ & $28,02 \mathrm{c}$ & $8,09 \mathrm{bc}$ & $37,00 \mathrm{e}$ & $8,33 \mathrm{c}$ \\
15 & $7,18 \mathrm{~d}$ & $27,98 \mathrm{c}$ & $7,89 \mathrm{bc}$ & $36,00 \mathrm{de}$ & $8,04 \mathrm{c}$ \\
\hline
\end{tabular}

Keterangan: Angka angka yang diikuti huruf sama dalam suatu kolom yang sama menunjukkan tidak berbeda nyata menurut uji DMRT 5\% 
1.000-butir gabah. Hal yang sama dilaporkan oleh Siregar et al. (2013), Solomon et al. (2014), dan Wangiyana et al. (2009).

\section{Kadar Protein dan Zn Beras Pecah-Kulit}

Hasil penelitian menunjukkan bahwa aplikasi pupuk kandang sapi yang diperkaya Zn meningkatkan kadar protein dan $\mathrm{Zn}$ beras pecah-kulit sampai batas dosis tertentu dan cenderung menurun seiring dengan bertambahnya dosis (Tabel 3). Senyawa protein disusun oleh $16 \% \mathrm{~N}$, di samping $\mathrm{C}, \mathrm{H}$, dan $\mathrm{O}$. Meningkatnya kadar $\mathrm{N}$ dalam tanah meningkatkan serapan $\mathrm{N}$, dan selanjutnya dapat meningkatkan kadar protein beras. Pupuk kandang sapi secara langsung dan tidak langsung membantu menyediakan unsur hara $\mathrm{N}$. Bahan organik dapat meretensi baik hara mikro maupun makro sehingga tidak mudah hilang dari zona perakaran (Kawano et al. 2009). Asam amino yang dihasilkan oleh sintesis protein pada tanaman menjadi lebih beragam oleh karena kadar hara lengkap. Kadar protein beras pecah-kulit meningkat seiring dengan meningkatnya dosis pupuk kandang sapi. Sementara (Tustiyani et al. 2014) menyatakan bahwa semakin tinggi pupuk organik yang diaplikasikan, semakin rendah kadar amilosa beras. Ini menandakan bahwa kadar proteinnya makin tinggi dengan ditambahkannya pupuk organik, Selanjutnya Hernawan \& Meylani (2016) melaporkan bahwa kadar protein beras organik lebih tinggi daripada beras non-organik.

Hasil percobaan ini menunjukkan bahwa kandungan $\mathrm{Zn}$ beras pecah-kulit meningkat seiring dengan bertambahnya dosis pupuk kandang sapi (Tabel 2). Peningkatan kandungan $\mathrm{Zn}$ ini dipicu oleh ketersediaan $\mathrm{Zn}$ yang bersumber dari pengayaan $\mathrm{Zn}$ secara langsung. Pernyataan ini sejalan dengan pendapat Shivay et al. (2007) bahwa aplikasi Zn yang ditambahkan dalam pupuk urea cukup efektif dalam meningkatkan kadar Zn dalam beras. Yadav et al. (2011) juga melaporkan bahwa aplikasi pupuk urea yang diperkaya Zn 1,5\% dapat meningkatkan hasil gabah dan serapan $\mathrm{Zn}$ dalam beras. Demikian pula, Tabassum et al. (2014) menjelaskan bahwa aplikasi pupuk kandang ayam 5 ton ha-1 yang ditambah pupuk $\mathrm{Zn} \mathrm{SO} 47 \mathrm{H}_{2} \mathrm{O} 10$ $\mathrm{kg} \mathrm{ha}^{-1}$ mampu meningkatkan kadar $\mathrm{Zn}$ dalam biji padi $20 \mathrm{mg} \mathrm{kg}^{-1}$. Lebih lanjut, Rozen et al. (2017) melapor- kan bahwa terjadi peningkatan kadar Zn sebesar 40,48 ppm dalam bulir padi yang diberi pupuk $\mathrm{Zn} 3 \mathrm{~kg}$.

Aplikasi pupuk kandang sapi menyumbangkan Corganik membuat ikatan kompleks dengan asam-asam organik dalama tanah. Fraksi asam humat dan asam fulvat dalam bahan organik tanah dapat menyerap unsur $\mathrm{Zn}$ sehingga ketersediaan $\mathrm{Zn}$ dalam tanah meningkat. C-organik yang tinggi menyebabkan $\mathrm{Zn}$ yang terekstraksi juga tinggi (Sillanpaa 1982). Selim (2015) juga mengemukakan bahwa pada beberapa contoh tanah dengan kandungan bahan organik yang tinggi, retensi $\mathrm{Zn}$ juga meningkat pelepasannya ke dalam larutan tanah berkurang. Hal ini dapat terjadi karena asam-asam dari bahan organik akan membentuk ikatan kompleks dengan $\mathrm{Zn}$ (Follet et al. 1981); asam-asam yang berasal dari dekomposisi bahan organik mampu mengikat $\mathrm{Zn}$ dan menjadikannya tersedia. Penggunaan pupuk organik dapat meningkatkan jumlah mikroorganisme tanah (Sujana 2014), yang selanjutnya dapat membantu ketersediaan unsur hara mikro tanah seperti Zn, besi, dan tembaga. Mishra (2014) melaporkan bahwa mikrob tanah mampu meningkatkan kadar $\mathrm{Zn}$ sebesar $0,08 \%$. Namun, pernyataan tersebut berbeda dengan Wissuwa et al. (2008), yang menyatakan bahwa bahan organik justru mengikat $\mathrm{Zn}$ dalam senyawa kompleks menjadi senyawa tidak tersedia bagi tanaman.

Hasil penelitian ini menunjukkan bahwa pemberian pupuk kandang sapi mampu meningkatkan kadar Zn dalam beras pecah-kulit. Apabila merujuk pada kebutuhan $\mathrm{Zn} 15 \mathrm{mg} /$ perhari bagi pria dan wanita dewasa, dengan asumsi komsumsi beras rata-rata 300 g per hari (Indrasari 2006), maka peningkatan kandungan $\mathrm{Zn}$ pada beras pecah-kulit hingga $37 \mathrm{ppm}$ mampu memberi asupan gizi mineral $\mathrm{Zn}$ bagi manusia yang mengomsumsi beras, serta belum melampaui ambang batas kadar Zn pada makanan (45 ppm) sehingga aman untuk dikomsumsi.

\section{Produksi}

Pengamatan kami menunjukkan bahwa aplikasi pupuk kandang sapi dengan dosis yang meningkat dapat meningkatkan produksi padi (Tabel 2) pada sistem budi daya pola SRI. (Solomon et al. 2014) melaporkan bahwa aplikasi pupuk kandang sapi 15 ton

Tabel 3 Pengaruh aplikasi pupuk kandang sapi yang diperkaya Zn pada pertambahan jumlah anakan dan anakan produktif tanaman padi varietas Mekongga pada sistem budi daya pola SRI

\begin{tabular}{|c|c|c|c|c|c|}
\hline \multirow{2}{*}{$\begin{array}{l}\text { Perlakuan dosis pupuk } \\
\text { kandang sapi ton } \mathrm{ha}^{-1}\end{array}$} & \multicolumn{4}{|c|}{ Jumlah anakan (hari sesudah tanam) } & \multirow{2}{*}{ Anakan Produktif } \\
\hline & 15 & 30 & 45 & 60 & \\
\hline Kontrol & $5,90 a$ & $29,63 a$ & $36,97 a$ & $36,13 a$ & $25,13 a$ \\
\hline 2,5 & $5,00 a$ & $34,93 b c$ & $45,10 b$ & $42,60 \mathrm{bc}$ & $28,53 \mathrm{bc}$ \\
\hline 5 & $5,27 a$ & $35,00 \mathrm{bc}$ & $45,47 b$ & $42,67 \mathrm{bcd}$ & $29,67 \mathrm{bcd}$ \\
\hline 7,5 & $5,33 a$ & $35,07 \mathrm{bc}$ & $48,57 b$ & $43,00 \mathrm{bcd}$ & $30,97 \mathrm{cde}$ \\
\hline 10 & $5,60 a$ & $35,23 c$ & $49,60 b$ & $44,70 \mathrm{bcd}$ & 33,00def \\
\hline 12,5 & $5,27 a$ & $35,80 c$ & $46,90 b$ & $46,67 d$ & $35,20 f$ \\
\hline 15 & $5,83 a$ & $35,07 \mathrm{bc}$ & $45,53 b$ & $45,63 \mathrm{~cd}$ & 33,95 ef \\
\hline Rata-rata & 5,41 & 34,36 & 45,40 & 42,93 & 30,49 \\
\hline
\end{tabular}

Keterangan: Rerata yang diikuti huruf sama dalam suatu kolom yang sama menunjukkan tidak berbeda nyata menurut uji DMRT 5\% 
ha $^{-1}$ dapat meningkatkan produksi padi. Selain dipengaruhi oleh ketersediaan hara, sistem budi daya juga diyakini memengaruhi hasil dan kualitas tanaman padi. Pada sistem budi daya pola SRI terutama pada pengaturan pengairan macak-macak hingga kapasitas lapangan yang menyebabkan oksigen tersedia, kondisi ini disukai oleh mikrob, dapat mempercepat proses mineralisasi, yang akhirnya dapat memasok nutrisi bagi tanaman (Ceesay 2004; Regazzoni et al. 2013), Penerapan pola SRI pada budi daya padi sawah mampu meningkatkan produksi tanaman (Masdar et al. 2006). Peningkatan produksi erat kaitannya dengan proses asimilasi tanaman pada periode vegetatif. Kemampuan tanaman mengakumulasi hasil fotosintentis menjadi bahan kering yang selanjutnya disuplai dalam bentuk biji. Oleh sebab itu, perlu ditambahkan unsur hara mikro seperti Zn pada pupuk organik yang digunakan pada tanaman. Pada penelitian ini aplikasi pupuk kandang sapi dosis 10 ton ha $^{-1}$ mampu menghasilkan produksi padi tertinggi (Tabel 2). Penambahan dosis pupuk kandang sudah tidak memengaruhi peningkatan produksi.

Hasil analisis regresi (Gambar 2) menunjukkan hubungan antara parameter amatan dan dosis
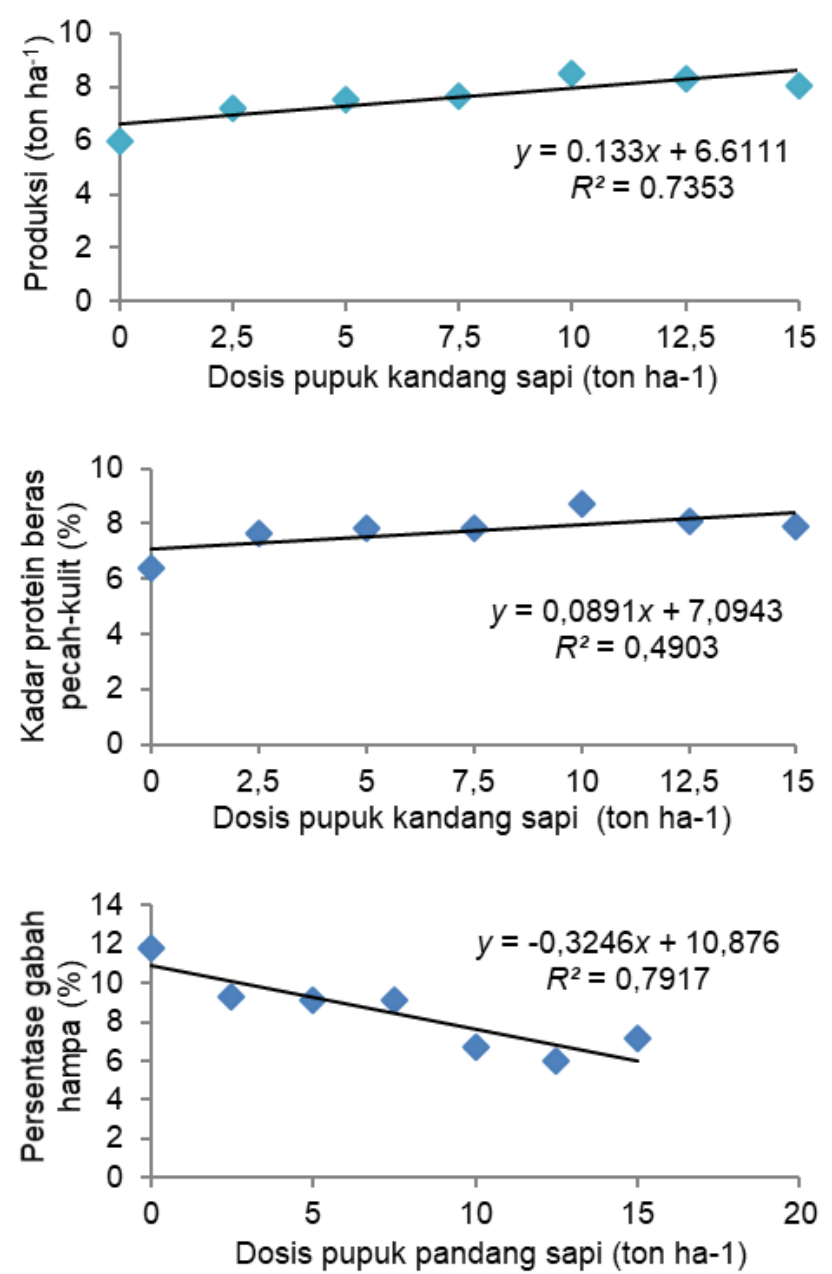

Gambar 2 Korelasi antara perlakuan berbagai dosis pupuk kandang sapi terhadap (A) produksi, (B) kadar Zn beras pecahkulit, (C) kadar protein beras pecah-kulit, (d) bobot 1.000-butir padi, (E) persentase gabah hampa; (F) jumlah anakan produktif perlakuan berkorelasi positif. Semakin meningkat dosis pupuk kandang sapi yang diaplikasikan semakin banyak jumlah anakan produktif, kadar protein, kadar Zn, bobot 1.000-butir, dan produksi padi, sebaliknya, semakin berkurang persentase malai hampa. Hal tersebut tidak lepas dari peran dan fungsi pupuk kandang sapi melalui efeknya pada sifat fisik, kimia, dan biologi tanah, yang secara tidak langsung memengaruhi penyerapan unsur hara mikro. Peningkatan seiring dengan penambahan dosis pupuk kandang sapi hingga dosis tertentu. Karbon-organik yang terdapat pada pupuk kandang sapi dapat meningkatkan kesuburan tanah dan penggunaan hara secara efisien; hal ini tampak pada parameter khususnya produksi dan kualitas padi.

\section{KESIMPULAN}

Aplikasi pupuk kandang sapi 12,5 ton ha-1 yang ditambah $\mathrm{Zn} 5 \mathrm{~kg} \mathrm{ha-1}$ dapat meningkatkan jumlah anakan dan anakan produktif, menurunkan persentase gabah hampa, meningkatkan bobot 1.000-butir 9,92\%, meningkatkan produksi dan kadar $\mathrm{Zn}$ dalam beras
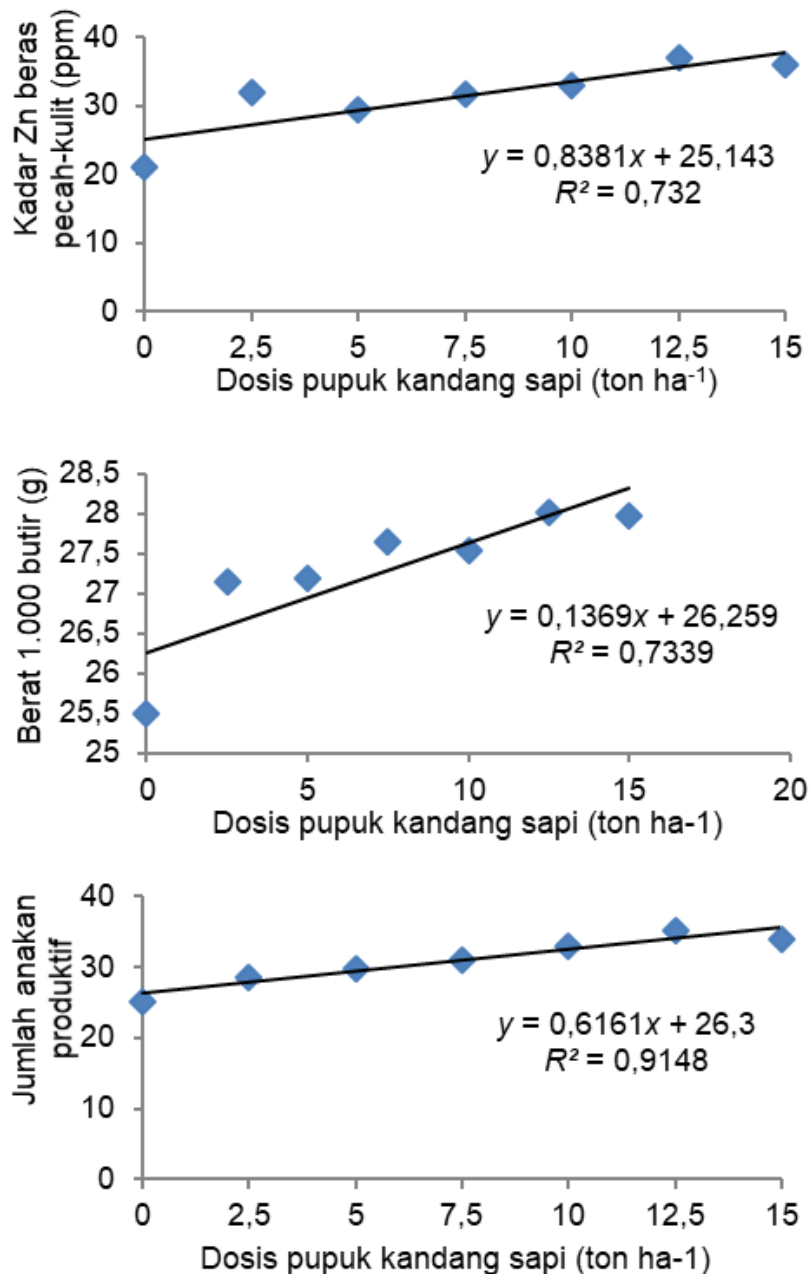
pecah-kulit 27,59\% pada sistem budi daya pola SRI di lahan sawah inseptisol yang diolah secara intensif.

\section{UCAPAN TERIMA KASIH}

Kami mengucapkan terima kasih kepada Pimpinan dan staf Balai Pengkajian Teknologi Pertanian Kebun Percobaan (BPTP-KP) Sidondo Sulawesi Tengah, atas bantuan dan fasilitas yang telah diberikan.

\section{DAFTRA PUSTAKA}

Alloway BJ. 2008. Zinc in Soils and Crop Nutrition. 2nd edition. Brussels (BE) and Paris (FR): IZA and IFA.

Ardianti D, Sudiarso. 2019. Pengaruh pupuk anorganik dan pupuk hayati pada pertumbuhan dan hasil tanaman jagung manis (Zea mays saccharata Sturt.). Jurnal Produksi Tanaman. 7(10):1814-1820.

Arsyad M, Saud M. 2020. Evaluasi tingkat kualitas dan mutu beras hasil penggilingan padi di Kecamatan Duhiadaa Kabupaten Pohuwato. Jurnal Pertanian Berkelanjutan. 8(1): 8-18.

Azalika RP, Sumardi, Sukisno. 2018. Pertumbuhan dan hasil padi Sirantau pada pemberian beberapa macam dan dosis pupuk kandang. Jurnal IImu-IImu Pertanian Indonesia. 20(1): 26-32. https://doi.org/1 0.31186/jipi.20.1.26-32

Boonchuay P, Cakmak I, Rerkasem B, Prom-U-Thai C. 2013. Effect of different foliar zinc application at different growth stages on seed zinc concentration and its impact on seedling vigor in rice. Soil Science and Plant Nutrition. 59: 180-188. https://doi.org/10 $.1080 / 00380768.2013 .763382$

Ceesay MM. 2004. Management of Rice Production Systems To Increase Productivity in the Gambia, West Africa. [Thesis]. Ann Arbor (US): University Microfilms International.

Devar N, Rajpar I, Memon MY, Imtiaz M, Zlal-ulhassan. 2011. Mineral nutrient densities in some domestic and exotic rice genotypes. Pakistan Journal of Agriculture Agricultural Engineering Veterinary Science. 27(2): 134-142.

Esmaeilzadeh J, Ahangar AG. 2014. Influence of soil organic matter content on soil physical, chemical and biological properties. International Journal of Plant, Animal and Environmental Sciences. 4(4): 244-252.

Follet RH, Murphy LS, Donahue RL. 1981. Fertilizers and Soil Amendments. New Jersey (US): PrenticeHall inc.

Gardner FP, Pearce RB, Mitchell RL. 1991. Fisiologi Tanaman Budidaya. Jakarta (ID): UI Press.
Hamam M, Pujiasmanto B, Supriyono. 2017. Peningkatan hasil padi (Oryza sativa L.) dan kadar zink dalam beras melalui aplikasi zink sulfat heptahidrat. Jurnal Agronomi Indonesia. 45(3): 243-248. https://doi.org/10.24831/jai.v45i3.12287

Hernawan E, Meylani V. 2016. Analisis karakteristik fisikokimia beras putih, beras merah, dan beras hitam (Oryza sativa L., Oryza nivara dan Oryza sativa L. indica). Jurnal Kesehatan Bakti Tunas Husada. 15(1): 79-91.

Indrasari SD. 2006. Kandungan mineral padi varietas unggul dan kaitannya dengan kesehatan. Iptek Tanaman Pangan. 1(1): 88-99.

Indrasari SD, Daradjat AA, Hanarida I, Komari. 2007. Evaluasi karakteristik mutu giling, mutu tanak, dan kandungan protein-besi kompleks pada beberapa genotipe padi. Penelitian Pertanian Tanaman Pangan. 26(1): 62-68.

Jalali-moridani M, Amiri E. 2014. Effect of nitrogen and potassium on yield and yield components of rice cultivar "Hashemi". Indian Journal of Fundamental and Applied Life Sciences. 4(4): 417-424.

Janušauskaitè $D$, Arlauskienè $A$, Maikštènienè $S$. 2013. Soil mineral nitrogen and microbial parameters as influenced by catch crops and straw management. Zemdirbyste-Agriculture. 100(1): 9-18. https://doi.org/10.13080/z-a.2013.100.002

Kaihatu SS, Pasireron M. 2011. Adaptasi beberapa varietas unggul baru padi sawah di Morokai. Agrivigor: Jurnal Agroekoteknologi. 11(2): 178-184.

Kawano N, Ito O, Sakagami JI. 2009. Morphological and physiological responses of rice seedlings to complete submergence (flash flooding). Annals of Botany. 103(2): 161-169. https://doi.org/10.1093/ aob/mcn171

Krishna A. 2006. Influence of System of Rice Intensification (SRI) on Seed Yield Quality and Storability of Rice. [Disertasi]. Dharward (IN): University of Agricultural Science.

Mahmud Y, Nurlenawati N, Sugiarto H. 2011. Pengaruh macam perlakuan benih terhadap pertumbuhan dan hasil beberapa varietas unggul baru tanaman padi (Oryza sativa L.) di lahan sawah irigasi Kecamatan Tempuran Kabupaten Kerawang. Solusi. 9(17): 53-63.

Masdar, Kasim M, Rusman B, Hakim N, Helmi. 2006. Tingkat hasil dan komponen hasil sistem intensifikasi padi (SRI) tanpa pupuk organik di daerah curah hujan tinggi. Jurnal IImu IImu Pertanian Indonesia. 8(2): 126-131.

Mishra P. 2014. Rejuvenation of biofertilizer for sustainable agriculture and economic development. The Journal of Sustanaible Devoelopment. 11(1): 41-61. 
Mousavi SR. 2011. Zinc in crop production and interaction with phosphorus. Australian Journal of Basic and Applied Sciences. 5(9): 1503-1509.

Prasad AS. 2014. Zinc: a miracle element. its discovery and impact on human health. JSM Clinical Oncology and Research. 2(4): 1-7. https://doi.org/ 10.3945/an.112.003210

Purba JHH. 2011. Kebutuhan dan cara pemberian air irigasi untuk tanaman padi sawah (Oryza sativa L.). Widyatech Jurnal Sains dan Teknologi. 10(3): 145-155.

Purnomo D, Yunus A, Budiastuti S. 2011. Budidaya padi berwawasan lingkungan dengan metode system of rice intensification (SRI) dan penggunaan pupuk organik cair. Jurnal Ekosains. 3(1): 25-32.

Ratmini, NPS. 2014. Peluang peningkatan kadar seng (Zn) pada produk tanaman serealia. Di dalam: Prosiding Seminar Nasional Lahan Suboptimal; 26-27 September 2014. Palembang (ID). hlm 674-684.

Regazzoni O, Sugito Y, Suryanto A. 2013. Sistem irigasi berselang (intermittent irrigation) pada budidaya padi (Oryza sativa L.) varietas Inpari-13 dalam pola SRI (system of rice intensification). Jurnal Produksi Tanaman. 1(2): 42-51.

Rehman H, Aziz T, Farooq M, Wakeel A, Rengel Z. 2012. Zinc Nutrition in rice production systems: a review. plant and soil. 361(1-2): 203-227. https: //doi.org/10.1007/s11104-012-1346-9

Rengel Z. 2015. Agronomic aproaches to increasing zinc concentration in staple food crops. Impacts of Agriculture on Human Healt and Nutrition. 1: 1-8.

Rozen N, Hakim N, Gusnidar. 2017. Aplikasi unsur mikro pada padi sawah intensifikasi yang diberi pupuk organik titonia plus pada metode SRI. Journal of Soil and Land Utilization Managenment. 14(1): 1-12. https://doi.org/10.25077/js.14.1.19.20 17

Salawati, Basir M, Kadekoh I, Thaha AR. 2018. The effect of zn-enriched biochar on peroxide enzyme activity, auxin content, chlorophyll count and $z \mathrm{n}$ of rice in different flooding systems. Plant Cell Biotechnology and Molecular Biology. 19(5 \& 6): 196-204.

Saputra RA, Mulyawan R. 2021. Diagram DRIS untuk menilai keseimbangan hara tanaman jeruk siam banjar (Citrus suhuensis I.) di lahan pasang surut Desa Sungai Kambat Kecamatan Cerbon Kabupaten Barito Kuala. Prosiding Seminar Nasional Lingkungan Lahan Basah. Volume 6 Nomor 1. April 2021

Selim M. 2015. Phosphate in soils: interaction with micronutrients, radionuclides and heavy metals. Boca Raton (US): Taylor \& Fracis Group. CRC Pr.
Shivay YS, Kumar D, Prasad R. 2007. Effect of zincenriched urea on productivity. zinc uptake and efficiency of an aromatic rice-wheat cropping system. Nutrient Cycling in Agroecosystems. 80(2): 181-188.

Sillanpaa M. 1982. Micronutrient and the nutrient status of soils: a global study. Rome (IT): FAO Soil Buletin No. 48, Food and Agriculture Organization. http://www.fao.org/3/a-at167e.pdf

Siregar D, Marbun P, Marpaung P. 2013. Pengaruh varietas dan bahan organik yang berbeda terhadap bobot 1.000 butir dan biomassa padi sawah IP 400 pada musim tanam I. Jurnal Online Agroekoteknologi. 1(4): 1413-1421.

Solomon IR, Saddiq AM, Usman BH. 2014. Effects of some organic manures on $\mathrm{N}, \mathrm{P}, \mathrm{K}, \mathrm{Zn}$, and $\mathrm{Fe}$ uptake in straw and grains of rice in the soils of Lake Geriyo, Adamawa State, Nigeria. AmericanEurasian Journal of Agricultural \& Environmental Science. 14(7): 674-680.

Sudarmadji S, Haryono B, Suhardi. 1984. Prosedur analisa untuk bahan makanan dan pertanian. Yogyakarta (ID): Liberty.

Sujana IP. 2014. Rehabilitasi lahan tercemar limbah garmen dengan pemberian biochar. [Disertasi]. Bali (ID): Universitas Udayana.

Supadma AAN, Adnyana IM, Puja IN. 2013. Kajian unsur hara mikro tanah untuk peningkatan produksi pangan pada lahan sawah di Kecamatan Penebel, Tabanan. Agrtotrop: Journal on Agriculture Science. 3(1): 73-81.

Tabassum S, Jeet S, Kumar R, Dev CM, Kumar P, Rehana R. 2014. Effect of organic manure and zinc fertilization on zinc transformation and biofortification of crops in vertisols of Central India. Journal of Agricultural Science. 6(8): 221-231. https ://doi.org/10.5539/jas.v6n8p221

Tekwa IJ, Olawoye HU, Yakubu H. 2010. Comparative effects of separate incorporation of cowdung and rice husk materials on nutrient status of some lithosols. International Journal of Agriculture and Biology. 12(6): 857-860. Retrieved from http:// www.fspublishers.org

Tustiyani I, Sugiyanta, Melati M. 2014. Karakter morfofisiologi dan fisikokimia beras dengan berbagai dosis pemupukan organik dan hayati pada budidaya padi organik. Jurnal Agronomi Indonesia. 42(3): 187-194.

Wahyudi I. 2009. Serapan Tanaman jagung (Zea mays L.) akibat pemberian pupuk guano dan pupuk hijau lamptoro pada ultisol wanga. Jurnal Agroland. 16(4): 265-272.

Wangiyana W, Laiwan Z, Sanisah. 2009. Pertumbuhan dan hasil tanaman padi var. Ciherang dengan teknik 
budidaya "SRI (system of rice intensification)" pada berbagai umur dan jumlah bibit per lubang tanam. Crop Agro. 2(1): 70-78.

Welch RM, Graham RD. 2004. Breeding for micronutrients in staple food crops from a human nutrition perspective. Journal of Experimental Botany. 55(396): 353-364. https://doi.org/10.1093 /jxb/erh064

Wibisono IB, Mujiyono S. 2018. Segmentasi fuzzy Cmeans untuk membantu identifikasi kualitas beras berdasarkan nilai threshold, warna dan ukuran. Multimatrix. 1(1): 21-25

Wissuwa M, Ismail AM, Graham R D. 2008. Rice grain zinc concentrations as affected by genotype, native soil-zinc availability, and zinc fertilization. Plant Soil. 306: 37-48. https://doi.org/10.1007/s11104-007936 8-4
Yadav GS, Kumar D, Shivay YS, Singh N. 2011. Agronomic evaluation of zinc-enriched urea formulations in scented rice (Oryza sativa). Indian Journal of Agricultural Sciences. 81(4): 366-370.

Yullianida, Suwarno, Ardie SW, Aswidinnoor H. 2014. Uji cepat toleransi tanaman padi terhadap cekaman rendaman pada fase vegetatif. Jurnal Agronomi Indonesia. 42(2): 89-95.

Yulnafatmawita, Prima S, Aprisal, Hakim N. 2014. Pengaruh unsur mikro terhadap peningkatan hasil padi sawah yang diberi pupuk organik titonia plus. [Tesis]. Lampung (ID): Universitas Lampung.

Zahrah S. 2011. Aplikasi pupuk bokashi dan NPK organik pada tanah ultisol untuk tanaman padi sawah dengan sistem SRI (system of rice intensification). Jurnal IImu Lingkungan. 5(2): 114-129. 